\title{
Új, gyermekbántalmazás elleni irányelv egészségügyi szak- emberek számára - összefoglalás
}

\author{
New Guideline against Child abuse for Health Professionals - Summary
}

Szerzők: Scheiber Dóra $\triangle,{ }^{a}$ Katonáné Pehr Erika, ${ }^{b}$ Bíróné Asbóth Katalin, ${ }^{a}$ Tománé Mészáros Andrea, ${ }^{a}$ Várnai
Dóra, ${ }^{a}$ Kovács Zsuzsanna, ${ }^{c}$ Mészner Zsófia ${ }^{a}$
a: Nemzeti Egészségfejlesztési Intézet, b: Pécsi Tudományegyetem Állam- és Jogtudományi Kar, c:
Palánta Gyermekorvosi Rendelö Budapest XIII. kerület

Beküldve: 2016.08.24.

Kulcsszavak: veszélyeztetett gyermekek, gyermekközpontú igazságszolgáltatás, irányelv, jelzőrendszer

Keywords: endangered children, child in the focus justice, guideline, signal system

\section{BEVEZETÉS}

2016. május óta hatályos, „Az egészségügyi ellátók feladatairól gyermekek bántalmazásának, elhanyagolásának gyanúja esetén Emberi Erőforrások Minisztériuma szakmai irányelve" ${ }^{1}$

A WHO meghatározása szerint a gyermek bántalmazása és elhanyagolása (rossz bánásmód) magában foglalja a fizikai és/vagy érzelmi rossz bánásmód, a szexuális visszaélés, az elhanyagolás vagy hanyag bánásmód, a kereskedelmi vagy egyéb kizsákmányolás minden formáját, amely a gyermek egészségének, túlélésének, fejlődésének vagy méltóságának tényleges vagy potenciális sérelmét eredményezi, egy olyan kapcsolat keretében, amely a felelősségen, bizalmon vagy hatalmon alapul. Ezen WHO elvet követve, a 2012. évi C. törvény a Büntető törvénykönyvről XX. fejezet 208. §- szerint, az 1997. évi XXXI. törvény a gyermekek védelméről és a gyámügyi igazgatásról (Gyermekvédelmi Törvény) a zéró tolerancia elvét fogalmazza meg a $6 . \S(5)$ bekezdésében. Eszerint: „A gyermeknek joga van emberi méltósága tiszteletben tartásához, a bántalmazással - fizikai, szexuális vagy lelki erőszakkal -, az el- hanyagolással és az információs ártalommal szembeni védelemhez. A gyermek nem vethető alá kínzásnak, testi fenyítésnek és más kegyetlen, embertelen vagy megalázó büntetésnek, illetve bánásmódnak."

2012. évi C. törvény a Büntető törvénykönyvről XX. fejezet 208. § (1) bekezdés szerint, „A kiskorú nevelésére, felügyeletére vagy gondozására köteles személy - ideértve a szülői felügyeletet gyakorló szülő, illetve gyám élettársát, továbbá a szülői felügyeleti jogától megfosztott szülőt is, ha a kiskorúval közös háztartásban vagy egy lakásban él -, aki e feladatából eredő kötelességét súlyosan megszegi, és ezzel a kiskorú testi, értelmi, erkölcsi vagy érzelmi fejlődését veszélyezteti, bűntett miatt egy évtől öt évig terjedő szabadságvesztéssel büntetendő." A 2012. évi C. törvény a Büntető törvénykönyvről XX. fejezet 208. §- szerint büntetendő az a tizennyolcadik életévét betöltött személy is, aki tizennyolcadik életévét be nem töltött személyt búncselekmény vagy szabálysértés elkövetésére, illetve züllött életmód folytatására rábír vagy rábírni törekszik, bűncselekmény elkövetéséhez felajánl. 
2012-ben a gyermekbarát és gyermekközpontú igazságszolgáltatás évében Magyarországon több nemzetközi egyezménynek és állásfoglalásnak megfelelően, számos törvénymódosítás lépett érvénybe. A hazai szabályozások a következő felsorolt európai és nemzetközi dokumentumokkal vannak összhangban:

- Európa Tanács R(2008)11. sz. ajánlása a fiatalkorúak esetében alkalmazható büntetések és intézkedések európai szabályairól,

- Európa Tanács R(2010)1.sz. ajánlása a tagállamok számára az Európa Tanács Pártfogási Szabályairól,

- Az Európa Tanács Miniszteri Bizottságának 2010. november 17-én elfogadott - iránymutatása a gyermekbarát igazságszolgáltatásról,

- az ENSZ Gyermekjogi Egyezmény (1991.évi LXIV tv.) 40. cikke, amely kimondja, a büncselekményekben érintett gyermekek a koruknak és helyzetüknek megfelelő bánásmódra jogosultak,

- „Pekingi Szabályok” - a fiatalkorúak igazságszolgáltatásában alkalmazandó általános minimumkövetelményekről szóló 1985. november 29-én kelt 40/33-as ENSZ közgyúlési határozata,

- „Havannai Szabályok”- a szabadságuktól megfosztott fiatalkorúak védelmének szabályairól szóló 1990. december 14-én elfogadott 45/113-as számú ENSZ közgyúlési határozat,

- „Rijadi Iránymutatások” - a fiatalkorú búnözés megelőzéséről szóló 1990. december 14én elfogadott 45/112-es számú ENSZ közgyűlési határozat,

- „Tokiói Szabályok” - a szabadságelvonással nem járó szankciók minimumszabályairól szóló, 1990-ben született 45/110-es ENSZ közgyűlési ajánlás,

- ENSZ Gyermekjogi Bizottságának „Gyermeki jogok a fiatalkorúak igazságszolgáltatásában” című, 10. Általános Kommentárja,

- Európa Tanács Miniszteri Bizottságának 2010. november 17-én elfogadott, Gyermekbarát igazságszolgáltatásról szóló Iránymutatása,

- 2012. február 15-én az Európa Tanács Miniszteri Bizottsága elfogadta a Gyermekjogi Stratégiát (2010- 2015), benne a gyermekbarát szolgáltatás terjesztését is,

- 2016. április 4-én elfogadott, az Európa Tanács új Gyermekjogi Stratégiája (2016-2021), melynek egyik prioritása továbbra is a gyermekbarát igazságszolgáltatás,

- Európai Parlament és a Tanács 2016. május hó 11. napján létrehozott a büntetőeljárás során gyanúsított vagy vádlott gyermekek részére nyújtandó eljárási biztosítékokról szóló 2016/800. számú irányelve.

A törvényi változtatások hatására hazánkban a szexuális bántalmazás elévülési ideje nagykorúság betöltését követő 5 év. Elkövetők tekintetében a büntethetőség korhatára általánosságban 14 év, de az emberölést, életveszélyt vagy halált okozó testi sértést, rablást, illetve kifosztást elkövető, 12. évüket betöltő gyermekek is büntethetők lettek, ha megfelelő belátási képességgel rendelkeznek. Legsúlyosabb büntetésük 1-tól 4 évig tartó javítóintézeti nevelés lehet. A 2012-es törvénymódosítás óta, szándékos emberölésnek minősül a 14 év alatt öngyilkosságra való befolyás. A gyermekközpontú igazságszolgáltatás értelmében a pénzbírság helyett a közérdekű munka került előtérbe, kiskorúak esetében a zárt tárgyalások élveznek előnyt, kiemeltebb figyelmet kap a gyermekkorúak tájékoztatása az igazságügyi, gyámügyi eljárások, a meghallgatások során.

2015. év januárjától a megelőző pártfogó felügyelet bevezetésével kiszélesedett a pártfogó felügyelők munkája. A gyermekek védelméről és a gyámügyi igazgatásról szóló 1997. évi XXXI. Törvény 68/D. § (1) bekezdése értelmében a gyámhatóság a búncselekmény vagy az elzárással is sújtható szabálysértés elkövetése miatt indult védelembe vétel iránti eljárásban, vagy a már fennálló védelembe vétel mellett megkeresi a pártfogó felügyelői szolgálatot, hogy járjon el, készítsen környezettanulmányt, illetve a megelőző pártfogó felügyeletet hajtsa végre. A megelőző pártfogó felügyelet célja, hogy azok a gyermekek (fiatalok), akik környezetük, vagy más hatására közel kerültek ahhoz, hogy elinduljanak egy bűnelkövetői életforma irányába, megforduljanak és különböző módszerek segítségével helyes irányba fejlődjenek. Ebben a munkában szoros együttmúködésre van szükség a gyermekvédelmi szakemberekkel és gyámhivatalokkal. 


\section{MÓDSZERTAN}

Az Országos Rendőr-főkapitányság 2016. 08. 17-én elérhető Búnmegelőzési statisztikája szerint, közel 39 ezer 1-3 éves korú, hozzávetőleg 45 ezer 4-17 év közötti, míg a 18-24 éves korosztályban 84 ezer körüli volt a sértettek száma. ${ }^{2}$

A Nemzeti Egészségfejlesztési Intézet 2016-ban elektronikus felmérést indított védőnők, iskola védőnők, házi gyermekorvosok, iskolaorvosok és iskolapszichológusok között, mely kérdőívet közel 1000 szakember töltötte ki. A felmérés elsősorban a 2011 óta létező www.gyermekbantalmazas.hu weboldal és annak Facebook felületének kihasználtságára vonatkozott. A másik kiemelt terület a bántalmazott csecsemők egy nagyon szúk speciális csoportjára fókuszált, a megrázott csecsemőkre. A válaszadók kevesebb, mint 10\%-a találkozott a problémával, és ugyanennyien voltak, akikben felmerült a gyanú, hogy gondozóik megrázták a csecsemőt. A 2 év alattiak koponyasérülése, az 1 év alattiak végtagtörései hátterében gyakrabban áll bántalmazás és/vagy elhanyagolás. A megkérdezettek kicsit több mint 15\%-a számolt be arról, hogy 2 év alatti koponyasérült gyermek volt a praxisában, míg 1 év alatti gyermekek végtagtörése $5 \%$ körül mozgott. Ugyanakkor az Állampolgári Jogok Országgyúlési Biztosa (ombudsman) által 2009-ben végzett vizsgálat adatai szerint az egészségügyben dolgozók igen alacsony arányban (védőnők 13\%, egyéb egészségügyi alkalmazottak kevesebb, mint 5\%, háziorvosok és házi gyermekorvosok csupán 0,2\%) tettek eleget a törvény által előírt jelzőrendszeri kötelezettségüknek. A kedvezőtlen jelzési mutatók és számos precedens eset miatt egy konszenzus anyag készült, amely a „A gyermekbántalmazás és elhanyagolás megelőzése, felismerése és kezelése c. módszertani levél" továbbfejlesztett változata. ${ }^{3,4}$ Ez a szakdokumentum, „Az egészségügyi ellátók feladatairól gyermekek bántalmazásának, elhanyagolásának gyanúja esetén Emberi Erőforrások Minisztériuma szakmai irányelve." 5
Az irányelv tartalmában íróként és véleményezőként több egészségügyi szakmai kollégiumi tagozat, illetve szervezet vett részt. ${ }^{i}$

\section{EREDMÉNYEK}

$A z$ irányelv által érintettek köre minden egészségügyi ellátásban részesülő 0-18 éves gyermek, akinél felmerül a gyanú bántalmazásra vagy elhanyagolásra. Az irányelv 42 egészségügyi ellátó tevékenységét érinti. [1. táblázat]

$\mathrm{Az}$ irányelv korábbiakhoz képest megfogalmazott legfontosabb része, hogy kijelöli az egészségügyi ellátók számára az egyes súlyossági fokozatok esetén milyen ellátási és jelzési útvonal javasolt. [1. ábra] Az irányelv leírja az egyes bántalmazási formák jellemzőit, a felismerés lehetőségeit, kiemeli a megelőzés, dokumentálás, mérlegelés, jelzés menetét. A megelőzés szempontjából hangsúlyozza a kezdeti problémák, életvezetési nehézségek időben történő felismerését. Megerősíti, hogy a pontosságra törekvő dokumentáció meghatározó a körülmények feltárásakor. Leírja, hogy a súlyosság mérlegelése határozza meg a további intézkedések láncolatát. Bemutatja, hogy a mérlegelést követően a megadott algoritmus szerint hogyan indokolt a jelzési kötelezettséggel élni. Kifejti, hogy a kommunikáció során számolni kell azzal, hogy a gyermek bántalmazása/elhanyagolása igen érzékeny, érzelmekkel telített helyzet, amit a kötődési viszonyok erősen befolyásolnak, és ezt minden esetben tiszteletben kell tartani. A gyermekek bűntudatát feltétlenül enyhíteni kell, és ez a szexuális bántalmazás esetén kiemelten igaz. Felhívja a figyelmet a disszociációra, mikor a bántalmazott kívülállóként viszonyul saját sérelmeihez, bemutatja a Stockholm szindrómát, amikor a bántalmazott az elkövetőt bizonyos szempontból felmenti vétsége alól. Az irányelv hangsúlyozza, hogy meg kell erősíteni a szülőt abban, hogy gyermekével együtt segítségre szorul, ami feltételezi a társzakmák közötti együttmúködést.

\footnotetext{
' Az irányelv tartalomért felelősök köre a Gyermek alapellátás (házi-gyermekorvostan, Ifjúsági és iskolaorvoslás, védőnő) Tagozat mellett kiterjed az Igazságügyi orvostan, orvosszakértés és biztosítási orvostan Tagozatra, Gyermekpszichiátria Tagozatra, Szülészet és nőgyógyászat, asszisztált reprodukció Tagozatra és a Traumatológia és kézsebészet Tagozatra. Emellett véleményezték az Égés- és plasztikai sebészet, Háziorvostan, a Megelőző és népegészségügy, kórház higiénia orvostan, a Nukleáris medicina, az Oxyológia - sürgősségi orvostan, toxikológia, honvéd és katasztrófa orvostan, a Transzfúziológia és hematológia Tagozatok és egyéb szervezetek, mint Család Gyermek Ifjúság Kiemelkedően Közhasznú Egyesület, Kék-Vonal Gyermekkrízis Alapítvány, Budapest Főváros Kormányhivatala XV. Kerületi Gyámhivatal.
} 


\section{1. táblázat: Az érintett ellátók köre}

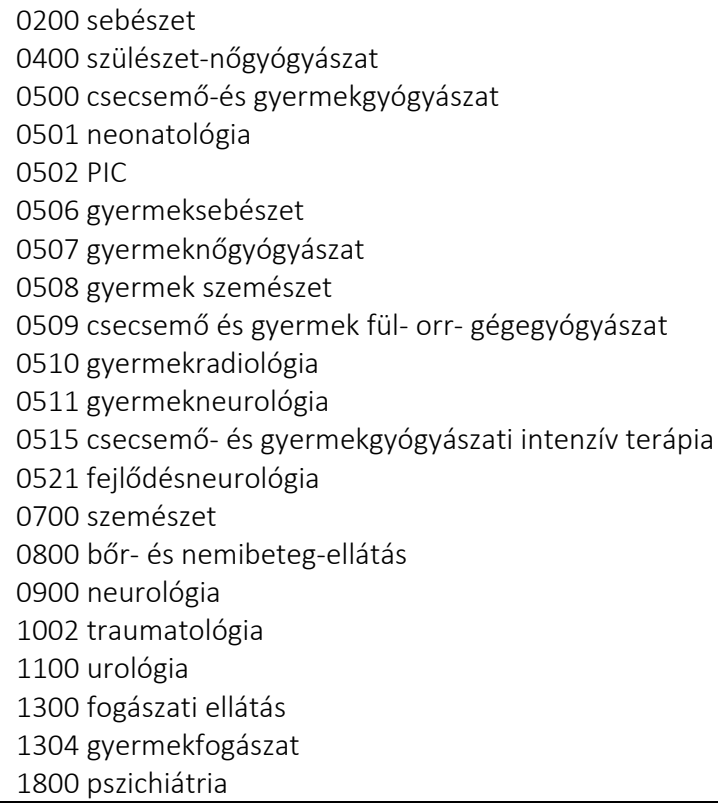

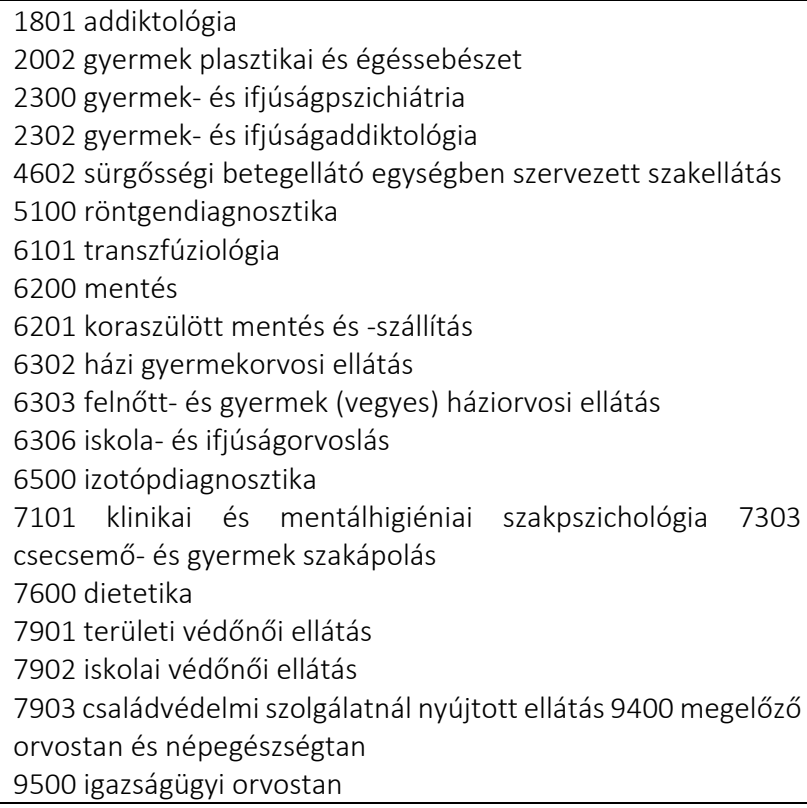

Forrás: Az egészségügyi ellátók feladatairól gyermekek bántalmazásának, elhanyagolásának gyanúja esetén Emberi Erőforrások Minisztériuma szakmai irányelve

1. ábra: Algoritmus az egészségügyi ellátók teendőiről a veszélyeztetettség észlelése esetén

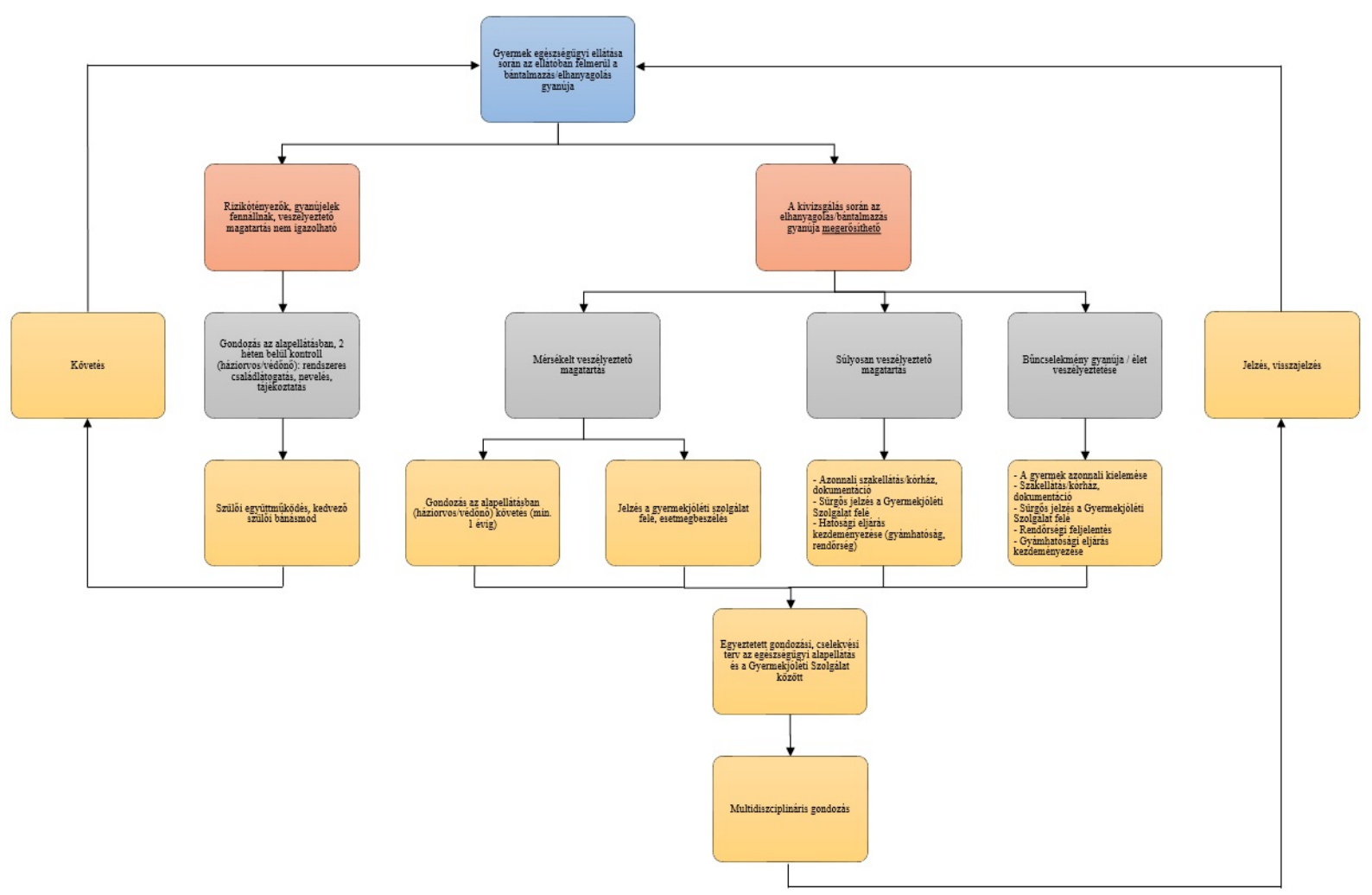

Forrás: Az egészségügyi ellátók feladatairól gyermekek bántalmazásának, elhanyagolásának gyanúja esetén Emberi Erőforrások Minisztériuma szakmai irányelve 
Az együttmúködés alapelveit és a jogi szabályozás kereteit „A gyermekvédelmi észlelő- és jelzőrendszer múködtetése kapcsán a gyermek bántalmazásának felismerésére és megszüntetésére irányuló szektorsemleges egységes elvek és módszertan" c. módszertani útmutató foglalja össze. ${ }^{6}$

A jelzőrendszer jelenlegi legnagyobb hiányossága, hogy amennyiben nem az egészségügy felől érkezik az elsődleges jelzés, úgy az egészségügyi ellátók nem kapnak kielégítő tájékoztatást a veszélyeztetés okáról, amik lehetnek:

1. Anyagi, egzisztenciális nehézségek;

2. Gyermeknevelési problémák;

3. Családi krízishelyzet:
a. válás
b. munkanélküliség
c. gyász
d. szülő betegsége, fogyatékossága

4. Szülók vagy a család életvitele:
a. szenvedélybetegség(ek): alkohol, drog, já- tékfüggőség,
b. és szenvedélybeteg személy: gyermek, testvér, apa, anya, egyéb gondviselő,
c. vándorló életmód,
d. bűnöző életmód,
e. promiszkuitásii, prostitúció

5. Elhanyagolás;

6. Családon belüli bántalmazás vagy annak gyanúja;
a. szülők közötti,
b. gyerekre irányuló,
c. testvére vagy más közös háztartásban élőre irányuló

7. Krónikus betegség, fogyatékkal élő gyermek vagy testvér;

8. Indokolatlan iskolai hiányzás;

9. Iskolai konfliktus;

10. Ideiglenesen vagy tartósan családjából kiemelt gyermek.

A veszélyeztetés okainak részletezése szükséges, mert differenciálhatja az egészségügyi szolgáltató ellátási formáját. Ugyancsak elengedhetetlen a jelzésre történő visszajelzés, hiszen ez jelenti a további összehangolt lépések, hosszabb távú együttmúködés alapját.

A különleges szükségletú gyermekek különösképp ki vannak téve a bántalmazásnak, elhanyagolásnak, alapvetően a rossz bánásmódnak. Különleges szükségletúnek tartjuk azt a gyermeket, aki tartósan beteg, illetve fogyatékos, továbbá életkoruk miatt a 3 év alatti gyermekeket. A Központi Statisztikai Hivatal 2016. augusztusi adatai alapján 7942 fő a különleges szükségletű gyermekek száma, ebből a 3 év alatti 2965 fő. A csoport 39\%-a él gyermekotthonokban. ${ }^{7}$

Speciális szükségletű az a gyermek, aki súlyos személyiségfejlődési zavarokkal küzd, illetve súlyos pszichotikus vagy neurotikus tüneteket mutat, vagy súlyos beilleszkedési zavarokat vagy súlyos antiszociális magatartást tanúsító gyermekkorú elkövető, illetve aki alkohol, drog és egyéb pszichoaktív szerek használatának problémájával küzd. A Központi Statisztikai Hivatal 2016-os adatai alapján a speciális szükségletű gyermekek száma 507 fő - az összes ellátottak 2,5\%-a, és közülük 27 él nevelőszülőnél. A kettős szükségletű, azaz egyidejúleg speciális és különleges szükségletú gyerekek színvonalas ellátása sajátos igényeket támaszt, és nagyon magas szakmai követelményeket feltételez. Magyarországon 2011-ben 177, 2012-ben 220, 2015-ben 243 föt fedett ez a csoport. ${ }^{8}$

Mindezen rizikófaktorok azért elgondolkodtatóak, mert pl. a tököli fiatalkorú fogvatartottak 78\%-a

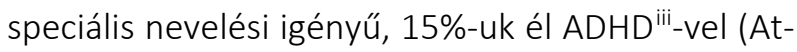
tention Deficit Hyperactivity Disorder), 35\%-a alacsonyabb IQ-val rendelkezik az átlagnál. Ezért a speciális szükségletű gyerekek felismerése, célzott ellátása és fokozott védelme az összes ellátórendszer minden szintjén nélkülözhetetlen a bűnelkövetés és áldozattá válás megelőzése szempontjából is. ${ }^{8}$

Az elkövetők nézőpontjából a gyermekkorúak és fiatalkorúak esetében a jóléti védelem elve kerül előtérbe, amit a bevezetőben felsorolt nemzetközi dokumentumok szabályoznak. A jóléti elv esetén az elsődleges kérdés kideríteni, miért követte el az adott

\footnotetext{
"ii promiszkuitás = alkalmi, nem tartós, válogatott partnerrel való nemi érintkezés

iii Attention Deficit Hyperactivity Disorder, ADHD =figyelemhiányos hiperaktivitás-zavar. Neurológiai_természetű veleszületett vagy fejlődési rendellenesség, melynek vezető tünete a figyelemzavar, kísérő tünetei a hiperaktivitás, feledékenység és a gyenge impulzuskontroll.
} 
személy a bűncselekményt. Az ellátás célja az egyéni szükségletre való reagálás, a magatartásváltozás elérése, lehetőség szerint a helyreállítást tartva szem előtt.

A Nemzetközi Gyermekjogi Hálózat álláspontja szerint a felelősség és a kriminalizálás szétválasztása szükséges. Ennek érdekében minden kétséget kizáróan meg kell tudni mi történt, milyen tényezők, indokok álltak a háttérben, és tisztázni kell a környezet és a szülők szerepét. Fel kell mérni, hogyan lehetett volna megelőzni az elkövetést, a gyermeknek milyen kezelésre, oktatásra, támogatásra van szüksége a búnismétlés megelőzése, teljes rehabilitációja érdekében.

Az Európa Tanács Miniszteri Bizottság Rec 2006/19 sz. ajánlása a tagállamok részére a pozitív szülői magatartás támogatásának politikájáról szól. ${ }^{8} \mathrm{~A}$ „Pozitív szülői magatartás" alatt a gyermek alapvető érdekein alapuló olyan szülői magatartás értendő, amely nevel, képességet fejleszt, erőszakmentes, eligazítást ad és irányt mutat, megszabja a határokat, és lehetővé teszi a gyermek teljes körű fejlődését. Eszerint a gyermekek érdekében külön hangsúlyt kell helyezni a szülők jogaira, így a szülói feladatok ellátásához az állami hatóságok részéről biztosítandó megfelelő támogatáshoz való jogra is. A szülők részéről a gyermekeik iránt viselt egyenlő és közös felelősség járul leginkább hozzá a gyermekek személyiségének harmonikus fejlődéséhez. Külön figyelmet kell fordítani az apák szerepének fontosságára gyermekeik gondozásában és nevelésében, különösen figyelembe véve a nemek közötti egyenlőség elvét, a munka és a családi élet összeegyeztetését és a család szétszakadását, ami gyakran azzal jár együtt, hogy az apák gyermekeiktől külön élnek. Mindezek biztosítása érdekében az állami kötelezettségeket hangsúlyozza a Bizottság - hivatkozással az európai családügyi miniszterek 28. ülésszakán (Portugália, Lisszabon, 2006. május 16-17.) kiadott záróközleményre és politikai nyilatkozatra -, különösen:

- „ „...elismerve, hogy - bár a szülői magatartás a család magánügye - azt közügynek kell tekinteni, és minden szükséges intézkedést meg kell tenni a szülők támogatására és a pozitív szülői magatartáshoz szükséges feltételek megteremtésére; emlékeztetve arra, hogy az Európa Tanács keretében kötelesek közös európai politikát támogatni és megvalósítani a családügyek és a gyermekek jogai terén;

- elismerve, hogy a gyermek jogokkal bíró személy, beleértve a védelemre és részvételre, véleményük kifejezésére, meghallgatásukra és a véleményük figyelembe vételére irányuló jogukat is;

- emlékeztetve arra, hogy az állami hatóságoknak rendkívül fontos szerepet kell játszaniuk általában a családok, és különösen a szülők támogatásában, amelynek a családpolitika három alapelemén keresztül kell kifejeződniük: állami juttatások és adózás, a munka és a családi élet közötti egyensúly megteremtése, gyermekgondozás és egyéb szolgáltatások;

- figyelembe véve, hogy a család a társadalom legfontosabb egysége, és a szülői magatartás alapvető szerepet játszik a társadalomban és annak jövőjében;

- tudatában annak a sok változásnak és kihívásnak, amellyel a családok manapság találkoznak, és amelyek megkövetelik, hogy a szülői szerep nagyobb figyelmet és jobb támogatást kapjon, figyelembe véve, hogy az ilyen támogatás elengedhetetlen a gyermekek, a szülók és a társadalom egésze számára; felismerve, hogy a társadalom minden szintjének szerepet kell játszania a gyermekek, szülők és családok támogatásában;

- figyelembe véve, hogy az állami hatóságok - a gazdasági és társadalmi szervekkel és a civil társadalommal karöltve -, a szülői szerep támogatására tett intézkedések révén segíthetik a társadalom egészségesebb és sikeresebb jövőjét, valamint a családi élet javítását célzó törekvéseket;

- tudomásul véve, hogy ágazatokon átnyúló és összehangolt megközelítésre van szükség;

- $\quad$ azon eltökélt szándéktól vezérelve, hogy a szülók támogatásának elengedhetetlen részeként, és a gyermekek jogai tiszteletben tartása és megvalósítása biztosításának eszközeként segítse a pozitív szülői magatartást." 


\section{ÖSSZEFOGLALÁS}

A veszélyeztetett gyermekek ellátása komplex feladat. Az elmúlt 5 évben számos intézkedés történt, mely ezen gyermekek magasabb színvonalú ellátását tǔzte ki célul. Az egészségügyi jelzőrendszer hatékonyabb múködése érdekében új irányelv került elfogadásra "Az egészségügyi ellátók feladatairól gyermekek bántalmazásának, elhanyagolásának gyanúja esetén Emberi Erőforrások Minisztériuma szakmai irányelve" címen. A veszélyeztetett gyermekek egyaránt lehetnek áldozatok és elkövetők, nemritkán áldozatok és elkövetők egyidejúleg. Emiatt az egészségügyi ellátóknak mindkét csoport ellátására fel kell készülniük. A lelki egészség megőrzésének, a harmonikus testi - lelki - szexuális fejlődésnek az egyén életében hosszú távú, mondhatjuk élethosszig tartó hatása van, a kiteljesedést, egészségben megélt éveket tekintve. Míg az ellenkezője is igaz: a gyermekkorból örökölt traumák hatását, még gyógyító és támogató segítségekkel is életen át hurcolhatják az áldozatok. Ezért kell minden lehetséges eszközzel, minden lehetséges színtéren küzdenünk a bántalmazás valamennyi formája ellen, időben megelőzni azt. Ezért ajánljuk figyelmébe a cikket és magát az irányelvet, a gyermekekkel foglalkozó egészségügyi szakembereknek.
Köszönetnyilvánítás

A szakmai irányelv egy konszenzus anyagon alapul, mely „A gyermekbántalmazás és elhanyagolás megelőzése, felismerése és kezelése c. módszertani levél,, továbbfejlesztett változata.

Ezúton köszönet illeti mindazon szervezeteket és intézményeket, akik a konszenzus anyag előkészítésében közremúködtek: Közigazgatási és Igazságügyi Minisztérium, Nemzeti Erőforrások Minisztériuma, Területi Gyermekvédelmi Szakszolgálat, UNICEF, Alapvető Jogok Biztosának Hivatal, Országos Rendőr-főkapitányság, Nemzeti Közszolgálati Egyetem, Igazságügyi Orvostani Intézet, Család Gyermek Ifjúság Egyesület, Magyar Védőnők Egyesülete, Házi Gyermekorvosok Egyesület, Kék-vonal Gyermekkrízis Alapítvány, Gyermekjóléti Központok, Nők a Nőkért Együtt az Erőszak Ellen (NANE) Egyesület, Értelmi Fogyatékosok és Segítőik Országos Érdekvédelmi Szövetsége (ÉFOÉSZ), Mental Disability Advocacy Centre (MDAC) iv, Jogismeret Alapítvány, Magyar Bírónők Egyesülete, Kézenfogva Alapítvány, Mérei Ferenc Fővárosi Pedagógiai és Pályaválasztási Tanácsadó, Független Média Központ Pandora Box, Pécsi Tudományegyetem (PTE), Nevelési Tanácsadók Egyesülete, Osztályfőnökök Egyesülete.

\footnotetext{
${ }^{1}$ http://www.hbcs.hu/uploads/jogszabaly/2339/fajlok/EEM szakami iranyelve.pdf (Elérve: 2016.08.17.)

2 http://www.police.hu/a-rendorsegrol/statisztikak/bunugyi-statisztikak (Elérve: 2016.08.17.)

3 http://www.ogyei.hu/upload/files/gyermekb modszertani ajanlas.pdf (Elérve: 2016.08.17.)

${ }^{4}$ http://www.ogyei.hu/upload/files/A\%20gyermekbantalmazas.pdf (Elérve: 2016.08.18.)

${ }^{5}$ http://www.hbcs.hu/uploads/jogszabaly/2339/fajlok/EEM szakami iranyelve.pdf (Elérve: 2016.08.18.)

${ }^{6}$ http://klik.gov.hu/download/e/60/c0000/A\%20gyermek\%20b\%C3\%A1ntalmaz\%C3\%A1s\%C3\%A1nak\%20felismer\%C3\%A9s\%C3\%A9re\%20\%C3\%A9s\%20megsz\%C3\%BCntet\%C3\%A9s\%C3\%A9re\%20ir\%C3\%A1nyul\%C3\%B3\%20egys \%C3\%A9ges\%20elvek\%20\%C3\%A9s\%20m\%C3\%B3dszertan.pdf (Elérve: 2016.08.19.)

7 https://www.ksh.hu/szocialis vedelem (Elérve: 2016.08.20.)

${ }^{8}$ A Miniszteri Bizottság Rec 2006/19 sz. ajánlása a tagállamok részére a pozitív szülői magatartás támogatásának politikájáról Elfogadta a Miniszteri Bizottság 2006. december 13-án a miniszterhelyettesek 983. ülésén -

https://issuu.com/csagyi/docs/csagyi 20106 (Elérve:2016.09.12)
}

\footnotetext{
iv Mental Disability Advocacy Centre (MDAC)= Mentális rendellenességek Érdekvédelmi Központ
} 